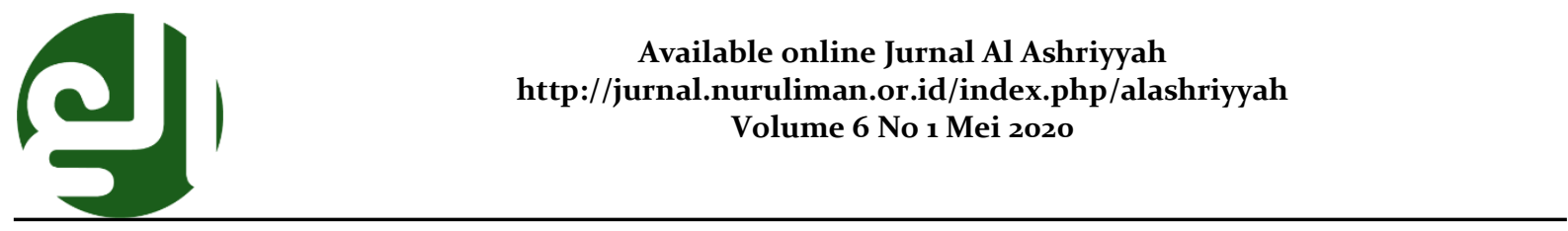

\title{
AL-TAUBAT DALAM PERSPEKTIF HADIS NABI
}

\author{
Canra Krisna Jaya ${ }^{1}$ \\ Sekolah Tinggi Agama Islam (STAI) Nurul Iman, Parung - Bogor \\ Jl. Nurul Iman No. o1 Desa Waru Jaya RT: o1/o1, Kec. Parung, Kab. Bogor \\ Email: canrakrisnajaya@stai-nuruliman.ac.id \\ No. Tlp/WA: xxx xxx xxx
}

Diterima: 22 Maret 2020; Diperbaiki: 1 April 2020; Disetujui: 7 April 2020

\begin{abstract}
This article aims to explain how repentance is a form of confession of a servant for the mistakes he has made, seen from the perspective of the Hadith of the Prophet Muhammad. This study uses a type of literature study with a qualitative approach. The primary data used are several main books of Hadith, then several books of Hadith Syarah. This article concludes that the teaching of repentance has consequences as well as implications for one's life. When repentance is understood in depth, it will be able to encourage someone to create a more positive life vision and mission. This is because an absolute truth or truth is only in the hands of God, so any falsehood should be returned to God as soon as possible in order to get the truth back. The truth and goodness that a person perceives are relative and relative, so he must be willing to have a dialogue about the truth by living it with steadfastness and not knowing stopping. Thus, repentance should not only be seen as a religious commandment, because in a deeper review, it turns out that it is able to guide a person to live a more wise, positive and constructive life.
\end{abstract}

Keywords: Repentance, Hadith Perspective

\begin{abstract}
Abstrak
Artikel ini bertujuan untuk menjelaskan, bagaimana taubat sebagai bentuk pengakuan seorang hamba terhadap kesalahan yang telah diperbuatnya, dilihat dari perspektif Haditz Nabi Muhammad Saw. Penelitian ini menggunakan jenis studi kepustakaan dengan pendekatan kualitatif. Data primer yang digunakan adalah beberapa kitab induk Hadits, kemudian beberapa kitab Syarah hadits. Artikel ini menyimpulkan bahwa ajaran taubat memiliki konsekwensi sekaligus implikasi terhadap kehidupan seseorang. Ketika taubat dipahami secara mendalam maka akan mampu mendorong seseorang utnuk membuat visi dan misi kehidupan yang lebih positif. Demikian ini karena sebuah kebenaran atau kebenaran absolut hanya ditangan Tuhan, sehingga kebatilan apapun seharusnya segera mungkin dikembalikan pada Tuhan agar mendapatkan kebenarannya kembali. Kebenaran dan kebaikan yang dipersepsikan seseorang bersifat nisbi dan relatif, sehingga ia harus bersedia melakukan dialog, tentang kebenaran tersebut dengan menjalaninya dengan ketabahan dan tidak mengenal kata henti. Dengan demikian taubat seharusnya tidak hanya dipandang sebagai perintah agama sematamata karena dalam tinjauan yang lebih dalam, ternyata ia mampu membimbing seseorang untuk menjalani kehidupan secara lebih arif, positif dan konstruktif.

Kata Kunci: Taubat, kebenaran dan Perspektif Hadits
\end{abstract}

${ }^{1}$ Canra Krisna Jaya Lubis lahir di Pakantan Dolok o3 Oktober 1989. Lulus S1 dari IAIN Medan dan S2 dari UIN Jakarta. Sekarang sedang menempuh program doktor di UIN Syarif Hidayatullah Jakarta. Saat ini tercatat sebagai dosen tetap di STAI Nurul Iman Parung Bogor. 


\section{PENDAHULUAN}

Untuk memulai pembahasan topik ditas, terlebih dahulu ada baiknya kita renungkan kembali firman Allah dalam QS. An-Anasr: 3 sebagai berikut:

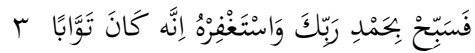

Maka bertasbihlah dengan memuji Tuhanmu dan mohonlah ampun kepada-Nya. Sesungguhnya Dia adalah Maha Penerima taubat. ${ }^{2}$

Sebagaimana perintah Allah SWT yang lain, perintah untuk senantiasa bertasbih dan bertaubat, ini sesungguhnya mengandung hikmah yang teramat dalam. Dengan mengimpelementasikan ajaran ini, manusia bukan saja hanya terhindar dari azab Tuhan akan tetapi lebih jauh, dan ini yang selalu dicar-cari oleh para pengelana kehidupan, ia akan menemukan kesejatian makna kehidupan. ketika mausia tidak lagi merasa paling benar tidak "sok suci" akan tetapi senantiasa sadar bahwa ia bisa benar dan bisa salah serta bisa lurus dan bisa juga menyimpang. Maka sesungguhnya telah menumbuhkan sikap hidup yang positif yang pada gilirannya akan membuatnya lebih "dewasa" dan lebih "arif" dalam mengharungi kehidupan di dunia ini.

Hanya saja kenyataan hidup sehari-hari, kita bisa lihat betapa banayak manusia yang merasa dirinya yang paling benar dan yang paling baik sementara oranglain dipandang lebih rendah. Apalagi ketika ia mampu melihat dirinya mampu menguasai

\footnotetext{
${ }^{2}$ QS: An-nashr 110:3.
}

serta mengendalikan yang lain. ${ }^{3}$ Alihalih telah merasa mampu segalagalanya dan tidak lagi bisa menerima saran dan kritik yang pada ujungnya akan membuat dirinya menjadi tiranik dan malah-malah bisa menjadi musyrik.

Berangkat dari pandangan diatas, pembahasan tentang taubat, tetap saja relevan dan aktual untuk dilakukan kapan saja dan dimana saja. Tulisan berikut ini mencoba mengkolaborasikan ajaran taubat dalam tinjauan hadis Nabi. Pertanyaan pokok yang segera bisa diajukan adalah: bagaimana petunjuk Nabi Muhammad SAW mengenai ajaran taubat?

\section{PEMBAHASAN}

\section{A. Pengertian Taubat}

Kata al-Taubat, dalam bahasa indonesia menjadi tobat ini, ${ }^{4}$ kata ini berasal dari bahasa arab yaitu taba, yatubu, mataban, yang berarti arruju' yang apabila diiringi dengan huruf jar "ila" maka maksutnya adalah seorang yang kembali kepada Tuhan dengan membawa penyesalan. Apabila didahului huruf jar "ala" maka maksutnya Tuhan datang kepada hambanya dengan membawa ampunan kepadanya "tawwaburrahim" zat

${ }^{3}$ Perhatikan firman Allah SWT yang terdapat dalam surah al-Alaq 96: 6-7 berikut "Ketahuilah! sesungguhnya manusia benarbenar melampaui batas. karena Dia melihat dirinya serba cukup"

4 Taubat diartikan sebagai tindakan sadar dan penyesalan akan dosanya (perbuatan salah ataupun perbuatan jahat yang lalu) dan berniat ingin memperbaiki tingkah laku dan perbuatannya tersebut. Lihat dalam kamus Umum bahasa Indonesia, Cet. VII (Jakarta, Balai Pustaka, 1996), h. 1064. 
penerima taubat lagi maha penyayang. ${ }^{5}$ Sementara itu Ibnu Mandzur mendefinifsikan taubat sebagaiberukut yakni: "kembalinya seseorang dari kemaksiatan menuju kepada ketaatan kepada Allah SWT".

Dalam kitab al-Ta'rifat, taubat didefinisikan sebagai sikap untuk kembali kepada Allah dengan menghilangkan kotoran-kotoran dalam hati, kemudian melaksanakan (menegakkan) hak-hak Tuhan. Sedangkan taubat nasuha adalah memperkuat keinginan untuk tidak lagi mengulangi perbuatan dosa yang pernah terlanjur dilaksanakan seperti semula. ${ }^{7}$ Oleh karenanya taubat mengandung sebuah ajaran yang mengandung tiga dimensi yang tidak dapat dipisahkan antara satu dengan yang lainnya, yakni penyesalan dengan setulus hati, kemauan yang kuat untuk tidak mengulangi lagi perbuatan yang dilarang oleh Allah SWT dan berusaha untuk memberantas perbuatan yang dzalim. Selanjutnya imam Al-ghazali dalam kitabnya al-Ihya Ulum al-Din, juz IV, sebagaimana yang dikutip Muhammad Mahzi 'Alam mensyaratkan taubat dalam tiga hal: Pertama: mengetahui dosa, kedua: menyesali perbuatan dosa itu, dan yang ketiga: berkemauan kuat untuk

${ }^{5}$ Muahammad mhzi Alam, Dairah alMaarif al-Islamiyah (Beirut: Dar al-Fikri, t.t.), Jilid V, h. 527.

${ }^{6}$ Ibn Manzur memberi pengertian taubat hampir serupa dengan "tobat" lihat lebih jauh, Ibn Mandzur, lisan al-Arab, Jilid I (Beirud: Daru Shadir, 1990), h. 233.

${ }^{7}$ Al- Syarif Ali bin M. al-Jurjani, Kitab alta'rifat, Cet. 3 (Beirut: Dar al-Kutub al-Ilmiyyah, 1988), h. 70. meninggalkan prbuatan dosa pada masa yang akan datang. Sepertinya persyaratan ini tidak berbeda jauh, bahkan mungkin serupa denagan dimesi taubat yang dilakukan oleh alJurjani dalam kitabnya "Kitab alTa'rifat".

Dari berbagai pengertian diatas maka dapat diambil kesimpulannya bahwa taubat adalah kembali kepada jalan yang benar dan meninggalkan perbuatan-perbuatan yang mungkar. Dengan demikian disatu sisi taubat juga berfungsi untuk menghambat tumbuhnya arogansi dalam diri manusia, tapi dalam sisilain juga berfungsi untuk menginjeksi kekuatan transendental spritual sehingga manusia mampu lebih tegar menjalankan perannya sebagai khalifah di muka bumi.

\section{B. Ajaran Dasar Hadis Tentang Taubat}

Sebuah upaya untuk meneliti hadis tentang taubat, penenulis menemukan data bahwa uraian uraian tentang taubat pada umumnya tidak ditemukan dalam satu bab tertentu baik dalam kitab kumpulan hadis maupun yang lainya. Walaupun sebenarnya dalam kitab shahih Muslim terdapat bab khusus mengenai taubat yang diuraikan dalam bab-bab lain yang lebih besar. ${ }^{8}$ Adakalanya ditempatkan dalam bab jihad, iman, washaya,al-zuhd, al-zakat, asyribah, da'at, al- kaffarat,dan yang lainnya. Mengapa hal ini terjadi? adalah suatu yang tidak penting dipersoalkan. Sebab kalaupun dicoba melakukan

\footnotetext{
${ }^{8}$ Al- Syarif Ali bin M. al-Jurjani..., h. 70.
} 
pengklasifikasian, sepertinya hal tersebut tidak terlalu sulit untuk dilakukan. Akan tetapi yang menjadi persoalan adalah apa dan bagaimana ajaran hadis mengenai taubat?

Uraian berikut akan mencoba membahas persoalan diatas dengan tetap memberikan kemungkinan untuk ditinjau kembali oleh siapa saja yang berminat untuk mengkaji dan mengembangkannya untuk yang lebih lanjut.

1. Ajaran untuk bertaubat

Dalam bab pendahulun sudah disinggung bahwa amplikasi dari pengalaman taubat ini akan membuat pelakunya hindar dari sikap menyombongkan diri. Menarik dikemukakan bahwa Allah SWT Memerintahkan Nabi dan umatnya untuk bertasbih dan beristigfar ketika kemenangan Islam telah datang dengan adanya fathul Makkah. ${ }^{9}$

Karena itu Nabi sendiri memberikan tauladan bahwa dirinya melakukan taubat tidak kurang dari tujuh puluh kali dalam sehari semalam Rasulullah shallallahu 'alaihi wa sallam bersabda,

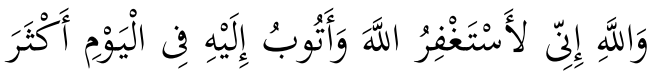

$$
\begin{aligned}
& \text { مِنْ سَبْعِينَ مَرَّةً }
\end{aligned}
$$

“Demi Allah. Sungguh aku selalu beristighfar dan bertaubat kepada Allah

\footnotetext{
${ }^{9}$ Renungkan kembali firman Allah dalam surat An-Nashr/110:1-3 berikut: “ jika telah datang pertolongan Allah dan kemenangan, dan kamu melihat manusia masuk agama Allah dengan berbondong-bondong, maka bertasbihlah dengan memuji Tuhanmu dan mohonlah ampun kepadaNya. Sesungguhnya dia adalah maha penerima taubat".
}

dalam sehari lebih dari 7o kali.” (HR. Bukhari)

$$
\text { Dalam riwayat lain }
$$
jugadijelaskan bahwa Rasulullah bertauabat kepada Allah sebanyak 100 kali dalam sehari.

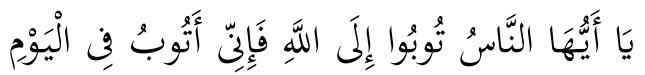

$$
\begin{aligned}
& \text { إلَالَيْهِه مِائَة مَرَّة }
\end{aligned}
$$

Dalam hal ini dijelaskan ada sebuah kisah sahabat yang bernama Hudzaifah radhiyallahu 'anhu berkata,

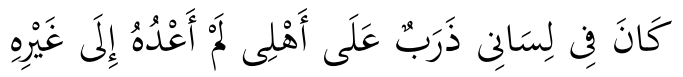

$$
\begin{aligned}
& \text { فَذَكَرْتُ ذَلِكَ لِلنَبَّيّ -صلى الله عليه وسلم }
\end{aligned}
$$

"Dulu lisanku biasa berbuat keji kepada keluargaku. Namun, aku tidaklah menganiaya yang lainnya. Kemudian aku menceritakan hal ini kepada Rasulullah shallallahu 'alaihi wa sallam. Beliau shallallahu 'alaihi wa sallam bersabda,

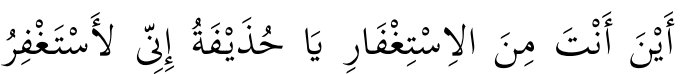

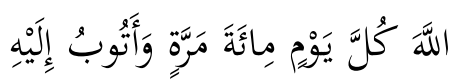

"Mana istigfarmu, wahai Hudzaifah? Sesungguhnya aku selalu beristigfar kepada Allah setiap hari sebanyak 100 kali dan aku juga bertaubat kepadaNya." (HR. Ahmad)

Dari penjelasan diatas bahwa sanya Rasulullah SAW bertaubat kepada Allah SWT sebanyak tujuh puluh kali dan dalam riwayat yang lain juga dijelaskan bahwa sanya Rasulullah 
SAW bertaubat kepada Allah SWT sebanyak seratus kali dalam satu hari. ${ }^{10}$

2. Penyesalan merupakan taubat

Dalam kitab ibnu majah disebutkan bahwa Nabi bersabda:

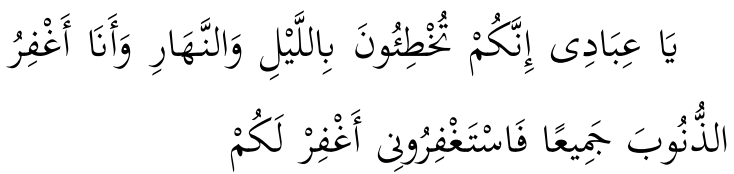

"Wahai hamba-Ku, sesungguhnya kalian berbuat dosa di waktu siang dan malam, dan Aku mengampuni dosadosa itu semuanya, maka mintalah ampun kepada-Ku, pasti Aku mengampuni kalian.” (HR. Muslim no. 6737).

Dari hadis diatas kita dapat penjelasan, bahwa diantar dimensi taubat adalah adanya sebuah penyesalan yang mendalam." Karena dalam kenyataannya dapat kita temukan sebagian dai manusia yang secara ritualistik melakukan dzikir, tasbih dan istighfar dengan istiqomah, tetapi tidak diiringi dengan sikap penyesalan atas perbuatan dosa atau kesalahan yang dilakukan. Dengan demikian penyesalan adalah suatu landasan sikap menuju taubat yang sebenarnya.

3. Pintu taubat selalu terbuka

Sebagai konsekuensi dari sifat Tuhan yang maha penerima taubat lagi maha penyayang, maka pintu taubatnya tidak pernah tetutup bagi siapa yang mau menghampiri-Nya. Ketika kita berbuat dosa dipetang hari, maka Allah SWT telah membentangkan

1o Imam Nawawi, syarah kitab shahih Muslim, Cet. I, Juz IX, No Hadits: 2702 (Beirut: Dar al-Hadis, 1994), h. 29.

${ }^{11}$ Lihat catatan kaki no. 7-8 "tangan -Nya” pada malam hari untuk memberikan ampunan. Demikian seterusnya jika kita berdo'a pada malam hari, lalu siang hari, maka Dia tetap membuka pintu bagi hambahamba-Nya yang mau bertaubat. Perhatikan sabda Nabi SAW berikut ini:

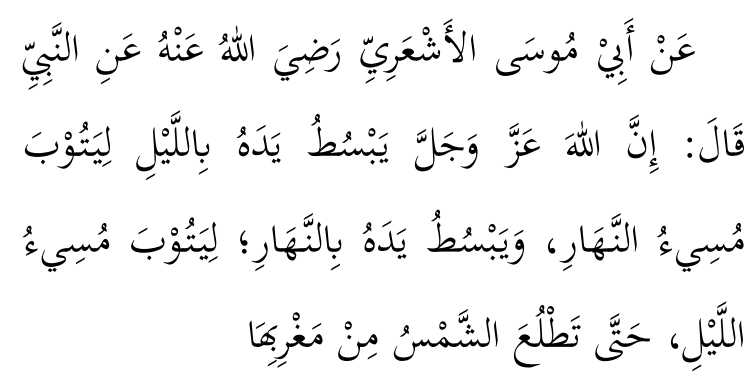

Diriwayatkan dari Abu Musa al-Asy'ari Radhiyallahu 'anhu dari Nabi Shalallahu 'alaihi wa sallam bersabda, "Sesungguhnya Allah 'Azza wa Jalla selalu membuka tangan-Nya di waktu malam untuk menerima taubat orang yang melakukan kesalahan di siang hari, dan Ia membuka tangan-Nya di waktu siang untuk menerima taubat orang yang berbuat salah di malam hari. Begitulah hingga matahari terbit dari arah barat." Shahih Muslim: 31 (2759)

Selanjutnya yang menarik dikemukakan bahwa "kedekatan" Tuhan dengan kita, seperti dijelaskan dalam Hadits berikut, adalah berbanding lurus dengan sejauh mana kita mendekati-Nya, bahkan Tuhan lebih dekat dari kita. Sebagaimana Hadits Nabi menjelaskan: " Dari Abu Hurairah r.a. bahwa Nabi muhammad SAW bersabda bahwa beliau bersabda: Allah berfirman: "Aku sesuai dengan parasangka hamba-Ku, dan Aku bersamanya manakala ia mengingat-Ku " sesungguhnya Allah lebih menykai 
taubat seorang hamba-Nya, dibanding seorang hamba yang mendekatiku sejengkal, maka Aku akan mendekatinya sehasta, maka siapa yang mendekatiku sehasta maka Aku akan mendekatinya sedepa, dan siapa yang menghampiriku dengan berjalan, maka aku akan menghampirinya dengan bergegas".

Meski demikian orang yang tidak mau mengingatkan kepada Allah maka Allahpun tidak akan mengingatnya. Nabi Muhammad membuat perumpamaan yang menarik bahwa orang yang mau mengingat Allah seperti "hidup", dan sebaliknya orang yang tidak mau mengingat Allah maka ia laksana seperti orang yang "mati".

4. Cara bertaubat

Dalam pembahasan ini, mengenai cara bertaubat manusi berbeda dengan malaikat, karena tidak satupun manusia yang tidak melakukan kesalahan. ${ }^{12}$ Sebab itu dalam ajaran Islam setip kali melakukan kesalahan, maka kita harus segera beristigfar kepada-Nya, lalu tidak mengulangi perbuatan terbsebut pada masa mendatang.

Penting dikemukakan bahwa Allah SWT tetapa mengampuni dosa hambanya kecuali dosa syirik, meskipun dosa itu setinggi langit dan sedalam lautan. Mari kita cermati firman Allah SWT berikut ini:

${ }^{12}$ Hadits yang masyhur mengenai ini adalah berbunyi: "setiap bani adam tidak telepas dari kesalahan"

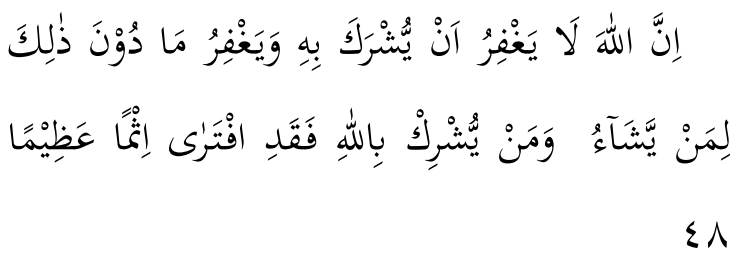

Sesungguhnya Allah tidak akan mengampuni dosa syirik, dan Dia mengampuni segala dosa yang selain dari (syirik) itu, bagi siapa yang dikehendaki-Nya. Barangsiapa yang mempersekutukan Allah, Maka sungguh ia telah berbuat dosa yang besar.

Penegasan firman Allah diatas yang terdapat dalam QS. An Nisa': 48 mengandung pengecualian untuk dosa syirik. Bahkan sebelum sampai tahap syirikpun, seperti sombong. Allah mengancamnya dengan ancaman azab neraka. Mari kita renungkan bunyi Hadits berikut ini:

Dalam sebuah hadits Qudsy dikatakan, "Wahai Bani Adam, kalian tidaklah (sungguh-sungguh) berdoa dan mengharap pada-Ku, Aku akan mengampuni dosa-dosa kalian dan Aku tidak peduli. Wahai Bani Adam, jikalau dosa kalian mencapai awan di langit, lalu kalian minta ampun pada-Ku, Aku akan mengampuni kalian, dan Aku tidak peduli. Wahai Bani Adam, jikalau kalian datang pada-Ku dengan dosa sebesar ukuran bumi, tetapi kemudian kalian mendatangiku dengan tanpa berbuat syirik pada-Ku, maka Aku akan datang padamu dengan ampunan sebesar itu pula." (HR. At-Tirmidzi).

Jadi apabila terdapat sedikit saja, baik itu misalnya sebesar biji sawi, rasa sombong dihati kita maka kita tidak bisa masuk surga, begitupula sebalknya 
apabila dihati kita ada iman meski seberat biji SAWi, kita tidak akan masuk neraka.

Adapun ucapan istigfar yang paling "ampuh" adalah seperti yang diriwayatkan oleh al-Bukhari. Bacaan istighfar yang paling sempurna adalah penghulu istighfar (sayyidul istighfar) sebagaimana yang terdapat dalam shohih Al Bukhari dari Syaddad bin Aus radhiyallahu 'anhu, dari Nabi shallallahu 'alaihi wa sallam, beliau bersabda, "Penghulu istigfar adalah apabila engkau mengucapkan,

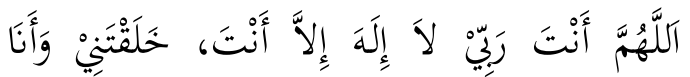

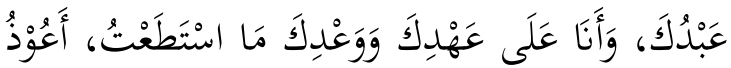

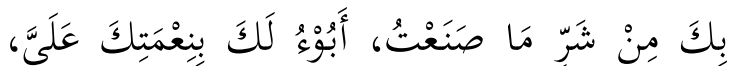

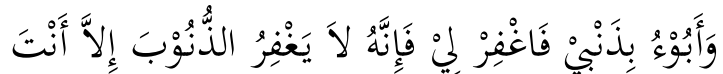

Ya Allah! Engkau adalah Rabbku, tidak ada Rabb yang berhak disembah kecuali Engkau. Engkaulah yang menciptakanku. Aku adalah hamba-Mu. Aku akan setia pada perjanjianku dengan-Mu semampuku. Aku berlindung kepada-Mu dari kejelekan yang kuperbuat. Aku mengakui nikmatMu kepadaku dan aku mengakui dosaku, oleh karena itu, ampunilah aku. Sesungguhnya tiada yang mengampuni dosa kecuali Engkau." (HR. Bukhari no. 6306).

Empat dimensi ajaran hadis diatas masih mungkin untuk ditambah lagi. Terutama bagi mereka yang berniat untuk mendalami dan mengembangkannya lebih lanjut. Misalnya pembahasan tentang keutamaan taubat, orang yang ditolak atau yang diterima taubatnya. Saat-sat yang makbul diterimanya suatu taubat dan lain sebagainya.

\section{KESIMPULAN}

Dari yang dipaparkan diatas, dapat dijelaskan bahwa ajaran taubat memiliki konsekwensi sekaligus implikasi terhadap kehidupan seseorang. Ketika taubat dimaknakan secara mendalam maka sesungguhnya ia harus mampu mendorong untuk memberikan visi pada seseorang, bahwa puncak kebenaran atau kebenaran yang absolut hanya ditangan Tuhan. Kebenaran dan kebaikan yang dipersepsikan seseorang bersifat nisbi dan relatif, sehingga ia harus bersedia melakukan dialog, tentang kebenaran tersebut dengan menjalaninya dengan ketabahan dan tidak mengenal kata henti. Dengan demikian taubat seharusnya tidak hanya dipandang sebagai perintah agama semata-mata karena dalam tinjauan yang lebih dalam, ternyata ia mampu membimbing seseorang untuk menjalani kehidupan secara lebih arif, positif dan konstruktif.

\section{DAFTAR PUSTAKA}

Alam, Muahammad mhzi. Dairah alMaarif al-Islamiyah. Beirut: Dar al-Fikri, t.t.

Ali, Al- Syarif. Kitab al-ta'rifat. Cet. 3. Beirut: Dar al-Kutub al-Ilmiyyah, 1988.

Mandzur, Ibn. lisan al-Arab. Jilid I. Beirud: Daru Shadir, 1990.

Nawawi, Imam. syarah kitab shahih Muslim. Cet. I, Juz IX, No 
Jurnal Al Ashriyyah, Volume 6 No 1 Mei 2020: 23-30

Hadits: 2702. Beirut: Dar alHadis, 1994. 